\title{
Production of Bioemulsifiers from Bacteria Grown on Hydrocarbons
}

\author{
Ghassan M. Ahmed \\ Assistant Lecture, Biotechnology Department/Institute of Genetic Engineering and Biotechnology for \\ Graduate Studies/University of Baghdad
}

\begin{abstract}
This work aimed to identify biosurfactant-producing bacterial strains isolated from hydrocarbon-contaminated sites and to evaluate their biosurfactant properties. The drop-collapse method and minimal agar added with a layer of diesel as carbon source were used for screening, positive strains were able to grow in a liquid medium, and surface tension and emulsification index were determined in cell-free supernatant and cell suspension. 250 bacterial isolate were tested, and 16 were positive for the drop-collapse and hydrocarbonlayer agar method. Most of the strains were Pseudomonas, except for three strains (Acinetobacter, Bacillus, and Rhodococcus). Surface tension was similar in cell-free and cell suspension measurements, with values in the range of 58 to $26(\mathrm{mN} / \mathrm{m})$, and all formed stable emulsions with engine oil $\left(77-92 \% \mathrm{E}_{24}\right)$. Considering the variety of molecular structures among microbial biosurfactants, they have different chemical properties that can be exploited commercially, for applications as diverse as bioremediation or degradable detergents.
\end{abstract}

Keywords: Biosurfactants, emulsifiers, soil flora, hydrocarbon contamination.

\section{Introduction}

One of the main causes of global contamination is the release of contaminants to the environment, including petroleum and petroleum-derived products (1), which also exert a risk for human and animal health since many of these contaminants have demonstrated to be toxic and carcinogenic (2). Microorganisms has proven to be effective to remove the effects soil and water contamination caused by hydrocarbon, using their metabolic abilities that can modify or use hydrocarbons as a source of carbon and energy. The compounds' chemical structure and its bioavailability (concentration, toxicity, mobility, and access) can affect the efficiency their degradation ${ }^{(3)}$. Many microorganisms produced Biosurfactants, to metabolize water-immiscible substrates, allowing its adsorption, emulsification,

\section{Corresponding Author:}

\section{Ghassan M. Ahmed}

Assistant Lecture, Biotechnology Department/ Institute of Genetic Engineering and Biotechnology for Graduate Studies/University of Baghdad e-mail: ghassan.m.ahmed@ige.uobaghdad.edu.iq or dispersion (4). Aerobic microorganisms, using as carbon sources, hydrocarbons, animal or vegetal oils, or a mixture of them mainly synthesizes microbial biosurfactants $(5,6)$. Biosurfactants can be remain attached to the cell wall (intracellularly) and/or could be released to the media $(7,8)$. A wide range of variation in biosurfactants physical and biological properties are allowed by the main difference in the hydrophilic head chemical nature ${ }^{(9)}$.

The term biosurfactant and bioemulsifier are considered interchangeable, but although all bioemulsifiers are considered biosurfactants, not all the biosurfactants produce stable emulsions. Biosurfactants reduce surface tension between two liquids, while bioemulsifiers induce dispersion of undissolved material throughout the liquid, by formation and stabilization of droplets of the dispersed phase ${ }^{(10,6)}$. Biosurfactants produced by Microorganisms are classified by its chemical composition and its microbial origin (10). Glycolipids or lipopeptides (Low molecular weight biosurfactants) can diminish surface tension but does not form stable emulsions ${ }^{(3)}$.

The biosurfactant-producing microbial strains is an interesting research area, due tothe wide variety of uses 
and the diversity of those molecules ${ }^{(11)}$. Several method were used for isolation and screening of interesting bacterial strains; the easiestcommon method is the drop-collapse test ${ }^{(12)}$, which has been described that the used carbon source to grow the microorganisms, is important on the identification of biosurfactants producing strains ${ }^{(5)}$. This work is an attempt to identify biosurfactant and/or bioemulsifier producing bacteria from soil bacterial isolates obtained from sites contaminated by hydrocarbon.

\section{Methods}

Bacterial Strains: Bacterial strains were isolated from soil contaminated obtained by selective enrichment ${ }^{(25)}$. Soil samples were taken and screened for hydrocarbon-degrading bacteria by inoculation into mineral salt agar $\left(\mathrm{Na}_{2} \mathrm{HPO}_{4} 6 \mathrm{~g}, \mathrm{KH}_{2} \mathrm{PO}_{4} 3 \mathrm{~g}, \mathrm{NaCl} 0.5 \mathrm{~g}\right.$, $\mathrm{NH}_{4} \mathrm{Cl} .1 \mathrm{~g}, \mathrm{MgSO}_{4} \cdot 7 \mathrm{H}_{2} \mathrm{O} 0.24 \mathrm{~g}$, and $\mathrm{CaCl}_{2} 0.01 \mathrm{~g}$, Bacto-Agar $15 \mathrm{~g}$, distilled water 1 l) without carbon source added to the plates, and were incubated at $25^{\circ} \mathrm{C}$ in a chamber saturated with gasoline vapors from 5-7 days. Colonies with different morphology were selected and inoculated into Tryptic Soy Agar (TSA) to obtain pure cultures, and periodical transfer into TSA to maintain strains $^{(13)}$.

Growth Conditions: Pure cultures were grown on broth added with glucose $(2 \% \mathrm{w} / \mathrm{v})$ olive oil, paraffin or sucrose $(1 \% \mathrm{w} / \mathrm{v})$, and incubated at $120 \mathrm{rpm}$ for five days, according to Bodour and Miller ${ }^{(12)}$. After incubation, biosurfactant production was tested. Cells were recovered by centrifugation $(12,000 \mathrm{x} \mathrm{g}, 5 \mathrm{~min})$ and suspended in $1 \mathrm{ml}$ of minimal saltbroth..

Biosurfactant production evaluation and Surface Tension Determination: The initial identification of biosurfactant-producing bacteria were done by dropcollapse method ${ }^{(14)}$. The tests were carried by triplicate, using culture supernatant and cell suspensions. Biosurfactant production was monitored in mineral salt agar plates added with a layer of a combustible material, according to the method proposed by Kiyohara et $a l .{ }^{(15)}$. Plates were inoculated aseptically transferring a bacterial colony with sterile toothpicks were incubated at $28^{\circ} \mathrm{C}$ for 7 days.

In the drop-collapse test, Positive bacterial strains were also evaluated for surface tension and stable emulsion formation. Strains were grown in minimal saltbroth added with sucrose (1\% w/v for Acinetobacter, Bacillus, Rhodococcus $)$ or glucose $(2 \% \mathrm{w} / \mathrm{v}$ for
Pseudomonas) and incubated for five days at $120 \mathrm{rpm}$. For measurements of surface tension, five $\mathrm{ml}$ of broth supernatant tube that was submerged in water bath at $28^{\circ} \mathrm{C}$. Surface tension was calculated by measuring the height reached by the liquid when freely ascended through a capillary tube ${ }^{(16)}$. The surface tension was calculated according to the formula (2):

$$
\gamma=\frac{\mathrm{rh} \delta \mathrm{g}}{2}
$$

$\gamma=$ Surface tension $(\mathrm{mN} / \mathrm{m})$;

$\mathrm{r}=$ capillary radius $(0.05 \mathrm{~cm})$;

$\delta=$ Density $(\mathrm{g} / \mathrm{mL})$;

$\mathrm{g}=\operatorname{gravity}\left(980 \mathrm{~cm} / \mathrm{s}^{2}\right) ;$

$\mathrm{h}=$ height of the liquid column (cm).

Emulsification Index Determination: Two $\mathrm{ml}$ of supernatant or cell suspension and $3 \mathrm{ml}$ of a selected hydrocarbon were mixed and vortexed in a test tube for 2 min and then maintained at $25^{\circ} \mathrm{C}$. The height of the emulsions layer were measured after $24 \mathrm{~h}$ to calculate the emulsification index ${ }^{(3)}$ according to the following equation used to determine the emulsification index $\left(\mathrm{E}_{24}\right)$ :

$$
E_{24}=\left(\frac{\text { height of emulsion layer }}{\text { height of total solution }}\right) \times 100
$$

\section{Results}

Bacterial Screening: Bacterial isolate were obtained from two different soils contaminated with hydrocarbons (diesel and used engineoil ${ }^{(17)} .250$ bacterial isolates were selected for the test of biosurfactants production based on their growth on minimal saltagar plates without a carbon source and incubated in a gasoline-saturated atmosphere.. Of all isolates, 82 were obtained from a site contaminated with used engine oil and 168 from a site contaminated with diesel. According to the initial characterization (colonial morphology, Gram stain, and biochemical tests), bacterial isolates belonged to the genera Pseudomonas, Rhodococcus, Bacillus, Micrococcus, Staphylococcus, Acinetobacter, and Serratia. All these genera were reported to be present in hydrocarbon-contaminated sites, and hydrocarbon degraders $^{(18,1)}$.

Some microorganisms produce biosurfactants in water-insoluble substrates, such as vegetable or mineral oils, while other microorganisms can produce these 
metabolites in presence of carbohydrates as carbon sources $^{(5)}$. All 250 bacterial isolates were grown in mineral salt supplemented with glucose, sucrose or olive oil, and the supernatant was used to select for biosurfactant-producing bacteria by the drop-collapse test. Sixteen isolates were positive and of those, 11 strains were growing in glucose, six in olive oil, and only three in sucrose; of those, three strains produced biosurfactants in olive oil as well as in glucose as substrates (Table 1).

Table 1: Production of Biosurfactant and identification of isolates grown in glucose, sucrose and olive oil as the carbon source

\begin{tabular}{|c|c|c|c|c|c|c|}
\hline Isolate & Source & Genera & Gram stain & Glucose & Sucrose & Olive oil \\
\hline S4M5 & Diesel & Pseudomonas & N & - & - & + \\
\hline S4M9 & Diesel & Pseudomonas & N & + & - & + \\
\hline S4Nb & Engine oil & Pseudomonas & N & + & - & - \\
\hline S4Nc & Engine oil & Pseudomonas & N & + & - & + \\
\hline S5B20 & Diesel & Rhodococcus & P & - & + & - \\
\hline S5C2 & Diesel & Pseudomonas & N & + & - & - \\
\hline S5C2c & Diesel & Pseudomonas & N & - & - & + \\
\hline S5Z2 & Diesel & Acinetobacter & N & - & + & - \\
\hline S6Ba & Engine oil & Pseudomonas & N & - & - & + \\
\hline ST -7 & Engine oil & Pseudomonas & N & + & - & - \\
\hline S1M2 & Diesel & Bacillus & P & - & + & - \\
\hline S2M7 & Engine oil & Pseudomonas & N & + & - & - \\
\hline S33c & Engine oil & Pseudomonas & N & + & - & - \\
\hline S22a & Engine oil & Pseudomonas & N & + & - & - \\
\hline S4d1 & Engine oil & Pseudomonas & N & + & - & - \\
\hline S4M2 & Diesel & Pseudomonas & N & + & - & - \\
\hline
\end{tabular}

The substrates used had been reported to promote biosurfactant production ${ }^{(14,19}$ and 20). Although the biodegradation capacity of the 250 isolates has not been tested by the reduction of hydrocarbons in pure culture, many are likely to degrade hydrocarbons since they were isolated in mineral salt agar plates, incubated in a hydrocarbon-saturated atmosphere as carbon source. However, only a small proportion were biosurfactant producers, which support the concept of the bacterial community, that will help other microorganisms to degrade the wide variety of hydrocarbons found at the $\operatorname{site}^{(21,4)}$.

The drop-collapse test was considered positive when within one minute, the drop expanded on the oily surface of the microplate lid. Besides the 16 positive isolates, another 21 strains (18 in olive oil, one in maize starch, one in sucrose, and one in paraffin) showed a partial collapsed drop after one minute, suggesting that those microorganisms produced only a small amount of biosurfactant, or it remained intracellular ${ }^{(14)}$.

The majority of the positive strains were identified as Pseudomonas spp., which are one of the most reported biosurfactant producer, and rhamnolipid had been reported that the most known biosurfactant that they produce ${ }^{(22,23)}$. Other Pseudomonas related microorganisms, such as Burkholderia plantarii ${ }^{(24)}$ and PS. chlororaphis ${ }^{(25)}$ also reported as biosurfactants producer.

The 16 isolates described in Table (1)were inoculated in amineral salt agar plate covered with a layer of a combustible material, a clear zone around the colonies was observed in the glucose-free plates after $24 \mathrm{~h}$ of incubation. Biosurfactantsare liberated to the surroundings and emulsification occurs as the main mechanism to introduce water-insoluble substrates to the cell interior ${ }^{(18)}$. 
Surface tension measurement showed that to give a positive drop collapse test, a surface tension lower than $45 \mathrm{mN} / \mathrm{m}$ was necessary. The surface tension of Mineral salt broth was $69.97 \mathrm{mN} / \mathrm{m}$. No differences were observed in the surface tension of cell-free supernatants and cell suspensions for all bacterial strains tested ( $>>0.05$, data are shown), opposing results obtained by Batista et al. ${ }^{(11)}$. The lower surface tension values, both with or without cells, was reached by Pseudomonas strains $(26.7 \mathrm{mN} / \mathrm{m})$ and were closely followed by the Bacillus strain $(33.32 \mathrm{mN} / \mathrm{m})$ (Table 2).

Even though lipopeptides produced by Bacillus are known as one of the most powerful microbial biosurfactants ${ }^{(9)}$, Pseudomonas rhamnolipids are also effective, and both of them are extracellular ${ }^{(29)}$. The important point is, if a surfactant that reduces the surface tension of water can form stable emulsions ${ }^{(11)}$. The term emulsifier is often used in an application-oriented manner to describe the combination of all the surface-active compounds that constitute the bioemulsifier secreted by the cell to facilitate the assimilation of an insoluble substrate ${ }^{(6)}$. As described in Table 2, most of the strains that had lower surface tension values were also the ones that formed the largest and more stable emulsions. In addition, there was no significant difference between the emulsions formed by the released biosurfactant or the cell suspension $(p>0.05)$. For all water-insoluble compounds tested, emulsions were more stable in the hydro carbonated portion of the oil-water mixture. When a supernatant without cells was used, emulsification index (after 24 hours) ranged from 0 to $99.9 \%$ for diesel, from 0.0 to $99.9 \%$ for kerosene, and from 76.2 to $92.8 \%$ for engine oil (Table 2). With high statistical differences between strains within each compound $(\mathrm{F}=15.55$ for diesel, $\mathrm{F}=99.9 .60$ for kerosene and $\mathrm{F}=2.35$ for engine oil respectively; $\mathrm{p}<0.01$ ). For decane, the emulsion index was in the range of $0-10 \%$ and there were no differences among strains $(\mathrm{p}>0.05)$.

The emulsification index can vary with bacterial growth phase ${ }^{(13)}$. The highest emulsification index values of diesel, kerosene, and engine oil were detected for Pseudomonas strains. Monteiro et al. ${ }^{(22)}$ reported an emulsification index of $70 \%$ after 30 days of incubation, demonstrating that emulsions produced by $P$. aeruginosa rhamnolipids are stable, and can be used in the control of environmental contamination. Only Bacillus and Acinetobacter formed stable emulsions with decane. Emulsions formed by Acinetobacter were small, but optically clear, probably due to vesicles rich in phosphatidylethanolamine that are formed, as observed by Desai \& Banat ${ }^{(10)}$, and the emulsion formed by Rhodococcus cells incorporated air in the emulsion, giving a column height higher than the controls.

\section{Conclusion}

Hydrocarbon contaminated sites can be considered as enrichment environments for the selection of hydrocarbon degrading and/or biosurfactant producing microbial strains. Production of biosurfactants and bioemulsifiers by soil microorganisms provides them with an advantage in contaminated sited, since they can use water-insoluble carbon sources for growth.

\section{Conflict of Interest: Nil.}

\section{Source of Funding: Self-funding}

Ethical Clearance: Ethical Clearance from the institutional ethical committee obtained for the study.

\section{References}

1 Rahman K, Rahman T, Korkoutas Y, Petsas I, Marchant R, Banat I. Enhanced bioremediation of $n$ - alcane in petroleum sludge using bacterial consortium amended with rhamnolipid and micronutrients. Bioresour. Technol. 2003; 90, 159168.

2 Prabhu Y, Phale P. Biodegradation of phenanthrene by Pseudomonas sp. Strain PP2: novel metabolic pathway, role of biosurfactant and cell surface hydrophobicity in hydrocarbon assimilation. Appl. Microbiol. Biotechnol.2003; 61, 342-351.

3.Christofi N, Ivshina I. Microbial surfactants and their use in field studies of soil remediation. J. Appl. Microbiol.2002; 93, 915-929.

4. Ron E. Rosenberg, E. Biosurfactants and oil bioremediation. Current Opinion Biotechnol. 2002; 13, 249-252.

5. Bognolo G.Biosurfactants as emulsifying agents for hydrocarbons. Colloids Surfaces A: Physicochem. Engineering Aspects. 1999; 152, 41-52.

6. Fiechter A.Biosurfactants: moving towards industrial application. Tibtech. 1992; 10, 208-217.

7. Bognolo G. Biosurfactants as emulsifying agents for hydrocarbons. Colloids Surfaces A: Physicochem. Engineering Aspects. 1999; 152, 41-52.

8. Lin SC. Biosurfactants: Recent advances. J Chem. Tech Biotechnol. 1996; 66:109-120. 
9. Lu JR, Zhao XB, Yaseen M.Biomimetic amphiphiles: biosurfactants. Current Opinion Colloid Interface Sci. 2007; 12, 60-67.

10. Desai JD, Banat IM. Microbial production of surfactants and their commercial potential. Microbiol. Mol. Biol. Rev.1997; 61, 47-64.

11. Batista SB, Mounteer AH, Amorim FR, Tótola MR. Isolation and characterization of biosurfactant/ bioemulsifier-producing bacteria from petroleum contaminated sites. Bioresour. Technol., 2006; 97, 868875 .

12. Bodour AA, Drees KP, Maier RM. Distribution of biosurfactant-producing bacteria in undisturbed and contaminated arid Southwestern soils. Appl. Environm. Microbiol. 2003; 69, 3280-3287.

13. Koneman E. Color Atlas and Textbook of Diagnostic Microbiology. $6^{\text {th }}$ Edition. Lippincott Williams \& Wilkins, USA.2005.

14. Batista, S.B.; Mounteer, A.H.; Amorim, F.R.; Tótola, M.R. Isolation and characterization of biosurfactant/bioemulsifier-producing bacteria from petroleum contaminated sites. Bioresour. Technol.2006; 97, 868875.

15. Kiyohara H, Nagao K, Yano K. Rapid screen for bacteria degrading water-insoluble, solid hydrocarbons on agar plates. Appl. Environm. Microbiol. 1982;43, 454-457.

16. Munguia $T$, Smith CA. Surface tension determination through capillary rise and laser difraction patterns. J. Chem. Educ.2001; 78, 343344.

17. Nevárez-Moorillón GV, Piñón-Castillo H, TorresMuñoz V, MuñozCastellanos LN,Vélez-Sánchez Verín C, Espinoza JV.et al. Soil contaminated with diesel (residual fuel no. 6). Remediation strategies. 2004; In Magar VI, Kelley ME. (eds). In Situ and On-site Bioremediation-2003. Battelle Press, Columbia OH. USA. Paper E-22
18. Bouchez M, Rakatozafy H, Marchal R,Leveau J, Vandecasteele J. Diversity of bacterial strains degrading hexadecane in relation to the mode of substrate uptake. J. Appl. Microbiol.1999; 86, 421428.

19. Olivera NL, Commendatore MG,Morán AC, Esteves JL. Biosurfactant-enhanced degradation of residual hydrocarbons from ship bilge wastes. J. Ind. Microbiol. Biotechnol.2000; 25:70-73.

20. Vipulanandan C, Ren X. Enhanced solubility and biodegradation of naphthalene with biosurfactant. J. Environm. Eng. Geophys.2000; 126, 629-633.

21. Rahman K, Banat I, Thahira J,Thayumamavan T,Lakshmanaperumalsamy, P. Bioremediation of gasoline contaminated soil by a bacterial consortium amended with poultry litter, coir pith and ramnolipid biosurfactant. Bioresour. Technol.2002; 81, 25-32.

22. Monteiro SA, Sassaki GL, Souza LM, Meira JA, Araújo JM, Mitchell DA. et al. Molecular and structural characterization of the biosurfactant produced by Pseudomonas aeruginosa DAUPE614. Chem. Phys. Lipids2007; 147, 1-13.

23. Wu JY, Yeh K, Lu WB, Lin CL, Chang JS. Rhamnolipid production with indigenous Pseudomonas aeruginosa EM1 isolated from oilcontaminated site. Bioresour. Technol.2008; 99, 1157-1164.

24. Andrä J, Rademann J, Howe J, Koch MHJ, Heine H,Zähringer U. et al. Endotoxin-like properties of a rhamnolipid exotoxin from Burkholderia (Pseudomonas) plantarii: immune cell stimulation and biophysical characterization. Biol. Chem.2006; 387, 301-310.

25. Gunther IV, NW, Nuñez A, Fett W, Solaiman DYK. Production of rhamnolipids by Pseudomonaschlororaphis, a nonpathogenic bacterium. Appl. Environm. Microbiol. 2005; 71, 2288-2293. 